\title{
DEVELOPMENT OF A METHODOLOGY FOR HOSPITAL BEDS PLANNING ACCORDING TO POPULATION AND MORBIDITY
}

\author{
HEINZ VAJASDI ${ }^{1}$, NONA DELIA CHIRIAC ${ }^{2}$, DANA GALIETA MINCA ${ }^{3}$ \\ ${ }^{1}$ PhDStudent, “Carol Davila” University of Medicine and Pharmacy, Bucharest, 2,3 “Carol Davila” University of Medicine and Pharmacy, Bucharest
}

Keywords: $\quad$ morbidity, Abstract: Introduction: Most of the forecast methods for hospital beds estimate a total number of beds hospital planning, beds per region, based on demographic and utilization indicators, without allocation on specialty wards. infrastructure

Objectives: Develop a forecast methodology per specialty in a county, according to the population needs. Materials and methods: Literature review, demographic data and indicators of hospital morbidity analysis; hospitalization rates adjustment for medical migration; model the allocation of new cases according to the previous hospitalization models. Results: the excess of hospitalization between similar counties varies between -34.71 to $96.50 \%$; adjustment of the hospital beds for patient migration leads to increase in the number of beds in 5 of 6 counties; the allocation of new cases, based on the previous model of hospitalization, triggers the reallocation between specialties. Conclusions: demographic indicators, hospital activity, family doctor records can be used successfully to design the number of beds at county level, according to the needs of the population.

\section{INTRODUCTION}

Projection of hospital resources according to the actual needs of population, while planning investments in building new structure or re-organizing the existing ones is critical to ensure the proper hospital care for the patients.

All healthcare policies need strong arguments in this regard, this is why there are a lot of methodologies proposed at local or global level (like WHO) for calculating the number of hospital beds according to the demographics trends of the population and forecasted utilization rates.

While these methodologies provide a general number of hospital beds in a certain area, they do not guide the beds allocation on specialties, thus there is not an obvious correlation between the types of the morbidity in a specific area and the number of necessary hospital beds per specialty in that area.

The accuracy of estimation of hospital beds on medical and surgical specialties is very important in projecting the need for the other structures, like operating theatres, and other medical resources and equipment.

When evaluating the population needs for hospital services, the medical migration is an important factor that could alter the statistics, if not properly considered.

\section{AIM}

The current paper aims to provide a methodology to project the number of hospital beds per specialty in a certain geographic area, by integrating information about the morbidity in the territory, with information about the pathology of hospitalized cases during a certain period of time, and utilization indicators. The method also takes into consideration the effect of the medical migration on the population served by the hospital.

\section{MATERIALS AND METHODS}

The analysis started with an internet research and review of the scientific literature regarding the methods to forecast the number of hospital beds, according to the demographics and the pathology of patients in a specific area. In our case, the area of interest is a selected county.

In order to allow the comparability of hospitalization rates from that county with the rates in similar counties or at national level, it was used the indirect standardization on age groups of the hospital inpatient rates according to the age groups in general population of Romania.

Adjustments for patient migration, considering comparison with hospitals on the same category, and the national statistics, have been done. We analysed the excess or deficit of hospitalization or surgical intervention in six counties, having over 500,000 inhabitants and type I hospitals. This type is the most complex in the country, there are university emergency hospitals having 34 different specialties, having a complex imagistic and nuclear medicine equipment and over $20 \%$ of the treated patients coming from other counties than the hospital.

The utilization rates were calculated using the data provided by the National Institute of Public Health and National School of Public Health, Management and Professional Development in Health, Bucharest.

We analysed the hospitalized cases in one particular year in that specific county, to investigate the model of allocating the inpatient cases of different pathologies on hospital wards. This model has been used afterwards to allocate the new cases registered at the family doctor on specialty wards, as basis to forecast the need of hospital bed on different medical specialties

\section{RESULTS}

In order to elaborate a methodology for forecasting the number of hospital beds in a county, we performed a literature

${ }^{1}$ Corresponding author: Heinz Vajasdi, Str. Doctor Leonte Anastasievici, Nr. 1-3, Cod 050463, București, România, E-mail: heinz.vajasdi@gmail.com, Phone: +40741 049324

Article received on 22.04.2019 and accepted for publication on 02.06 .2020 


\section{PUBLIC HEALTH AND MANAGEMENT}

review of the existing methods of prediction / modelling of the need for hospital beds. This identified several models of forecasts, proposed by the researchers for the planning of the beds. Out of these, the most popular are the following:

Formula method

The method of current use,

Model of the projection of the current use, of the status quo,

- The regression method,

- $\quad$ The stochastic method. $(1,2,3,4)$

All the above methods provide algorithms for calculating the number of beds considering demographics and usage indicators, but they do not take into account the pathologies that the hospital is supposed to treat.

A study conducted in 2011 showed that, "in Romania, the demand for health services is increasing, especially among the elderly population, the most requested services being those of cardiology, oncology and medical-social services".(5)

Considering the demographic evolution and dynamics of the various pathologies, it is necessary to estimate the hospital beds in a region or a county, not only as total number, but also by specialties, in order to plan a structure for that particular hospital that properly serve a specific population with its pathologies.

During the analysis of the indicators of the activity volume at the level of a certain county, carried out in a previous study, it was observed "a theoretical excess of beds, respectively of operating theatres, reported to the population of the respective county, by comparison with national averages".(6)

The study of the specialized literature has shown that the distribution of beds at regional / county level, based only the population of the respective area - although it is the most common method of allocating beds - has a major disadvantage. This does not consider the medical migration of patients residing in a county other than the county of the hospital to which they are addressed. This effect is more important especially the counties that host university centres.

This disadvantage is known in the international literature and the researchers have looked for different ways to adjust the number of beds according to this phenomenon.(7)

In this paper we analysed the situation of a county, anonymized in order to maintain the objectivity of the evaluation (identified under code $\mathrm{J} 2$ ). Within this county, in the period $2015-2017$ about $40 \%$ of the patients discharged from the hospitals from that county, came from other counties.

In order to estimate the real size of the impact of these patients on the real need for hospital services and structures in the studied county, we compared the county with the situation at national level, but also with similar counties in terms of population and types of hospitals.

Six similar counties were selected for comparison. They have university centres of medicine, population over 500,000 inhabitants and hospitals of categories I and II, according to Order 323/2011 - classification of hospitals according to competence and Order of the Minister of Health no. $1408 / 2011$ regarding the methodology for classifying hospitals according to their competence.(8)

The aim was to identify the effect of the county in which the hospital is located on the number of hospitalizations or hospitalizations. Given that similar counties, in terms of population and hospital services, were compared, one could expect to find that the rate of hospitalizations reported to the population of the county is similar, in the 6 counties. However, a previous study showed that, "following the comparison of the volume indicators of the activity in a county with a national average of 22.94 discharges/100 inhabitants, there were counties with clear excess of hospitalizations (Bucharest, Caraș Severin -
29.2\%, Alba, Hunedoara), others with deficits (Suceava $17.5 \%$, Mures, Iasi, etc.)".(9,10) The paper has shown that the number of beds in the county does not influence the excess of hospitalization.

The 2011 study showed the existence of real variations depending on the patient's home county, in the number of discharges and the average length of hospitalization. Regarding the cases with major surgeries, "there were notable differences between counties, measured by the excess or deficit of the standardized rate."

In order to eliminate the potential differences between the populations of the six counties studied in the present work, we applied the indirect standardization by age. Thus, we identified the excess or the deficit of hospitalization, in the compared counties, against an expected level according to the rates at national level (as standard rate of discharges we took the proportion of discharges by age groups from the population of Romania and was applied to the real population structure, by age groups in the respective counties).

Figure no. 1. Excess/deficit of hospitalization according to age group, 2016

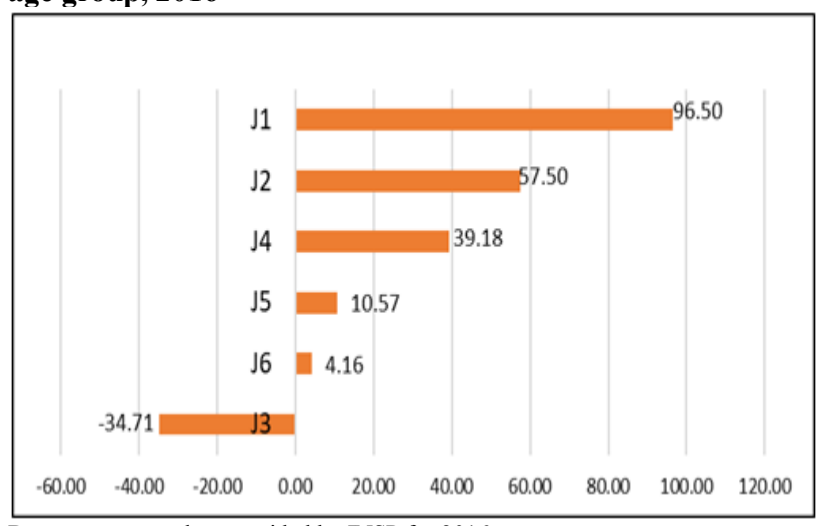

Data source: raw data provided by INSP for 2016

The null hypothesis was tested. It was assumed that the county of the hospital has no influence on the addressability of the patients. Applying the hi square test, it is observed that the null hypothesis can be rejected $(p=0.000)$ and it can be said that the county of the hospital influences the addressability of the patients (the number of discharges from other counties).

The proportion of patients from other counties treated in the county of the hospital is influenced by the county in which they are treated and is different between the counties.

Comparing the age-standardized discharge rates between the 6 counties studied, there is a significant excess of hospitalization in county $\mathrm{J} 1$, followed by county $\mathrm{J} 2$ and county $\mathrm{J} 4$, and a deficit in county J3. Further, given that the medical migration of patients between the counties is influenced by the county, and is different depending on it, it was necessary to develop a method of adjusting the number of beds according to the excess of hospitalization due to the medical migration, taking also considering the age standardization of the discharge rates.

Thus, according to the table no. 6 , we recalculated the population served by the hospital, by adjusting the population of the county with the excess of hospitalization, resulting in an "adjusted population". To the population thus adjusted with the excess due to the age standardization, we added an additional population, according to the proportion of patients from other counties who are admitted to the hospitals in the respective county. To this adjusted population, it was applied the average rate of coverage with beds at national level, 5.8 / 1000 inhabitants, obtaining new values for the total number of beds per county. 
Table no. 1. The adjustment of the number of beds per county, accounting for the age standardization and for the medical migration

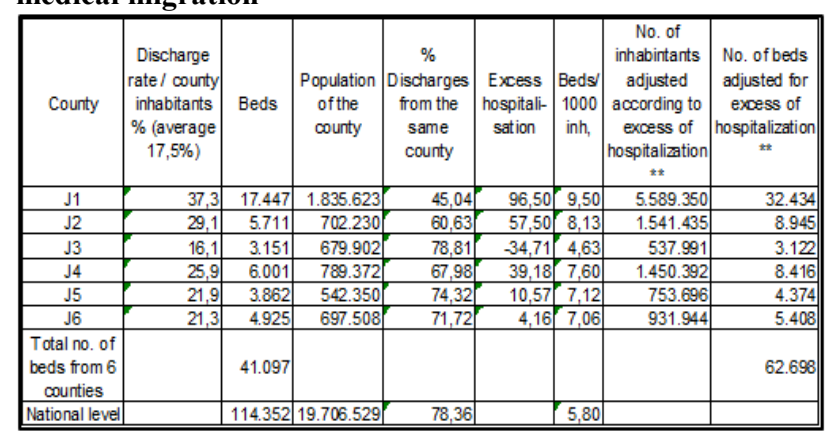

In 3 of the counties, the number of beds thus recalculated, shows values higher than the observed numbers: for instance, 32,434 in J1 compared to 17,447. In other three smaller counties, the recalculated values are similar or smaller than the observed number of beds (real, existing) - 3,122 recalculated beds compared to 3,151 real beds in J3.

The authors calculated the number of beds, days of hospitalization and discharged patients, per county and per type I hospital, in the studied counties; also, was calculated the market share of a hospital category 1, by reporting the hospital's own indicators to those of the county from which belongs.

There are differences between the market share of category I hospitals inside the county, in the 6 counties studied, between the counties (from $5 \%$ to $47 \%$ ). The market share is important when designing a new hospital or expanding a hospital, within a county, since is one of the variables that will have an impact on the number of beds of the new hospital.

We note that in the studied county (J2) the market share of the category I hospital is $28 \%$, as beds and number of discharges. This market share will be used to calculate how many beds a category I hospital should have, by specialty, from the total number of beds in the county.

Most of the methods of planning the number of beds result in the estimation of a total number of beds per hospital, without having an explicit connection with the need for hospitalization according to the types of pathologies in the respective area, but only with the demographic and the hospital usage indicators. a certain period.

And yet, the pathology is important, because there are variations between different areas and moments in time, from the point of view of the need for specialized care, and the use of specialized services.

Earlier studies in Romania showed that, between 2000 and 2009, consultations and treatments for different medical specialties varied as follows: "oncology and medicine of physical culture have increased, while surgery, phthisiology, dermato-venerology, ophthalmology, stomatology and ENT have decreased steadily. In the same period, new cases of diseases through diseases of the circulatory system, osteomuscle, nervous system and sense organs, as well as through endocrine and nutritional diseases, have increased.(5)

Designing the structure of a hospital in such way to cover the needs of the morbidity in the served population, we must integrate the information regarding the new cases reported by the family doctor (who will at certain moment in time address the hospital), with the hospitalization model of the inpatient cases, historically recorded in hospitals in that area. The integration of the information from the two levels - the family doctor and the hospital - has the role both to facilitate the prognosis of necessary hospital services and to ensure the continuity of care. "Continuity of care is an important aspect of its quality, being related to the patient's right to receive care based on the collaboration and partnership between the different public and private medical units".(11)

To perform an estimate of the required number of beds by specialty, at county level, the authors performed a mapping of the hospitalized cases in 2016, with the cases newly reported at the family doctor in the respective county.. The hospitalized cases were classified according to the major diagnostic categories (MDC) of the DRG classification, while the newly reported cases were classified with ICD 10 classification, version with 999 codes. The mapping was performed after the name of the MDC, respectively of the diagnostic class (list with 999 codes). Table no. 2 shows the correspondence between the two categories of classes, respectively between the hospitalized patients and the new ones registered with the family doctor, of the same class.

Table no. 2. Correspondence between discharges from the major diagnostic categories (MDC) of the DRG system and the new cases reported by the family doctor by diagnostic classes, in ascending order of the diagnostic class

\begin{tabular}{|c|c|c|c|c|}
\hline MDC Name & $\begin{array}{c}\text { No. of } \\
\text { validated cases } \\
\text { (hospitalization } \\
\text { episodes) }\end{array}$ & $\begin{array}{l}\text { Diagnostic } \\
\text { class } \\
\text { (999 codes) }\end{array}$ & $\begin{array}{c}\text { Class Name } \\
\text { Diagnosis }\end{array}$ & $\begin{array}{l}\text { New } \\
\text { registered } \\
\text { cases } \\
\text { family } \\
\text { doctors } \\
\text { (patients) }\end{array}$ \\
\hline $\begin{array}{l}\text { MDC 18. Infectious } \\
\text { and } \\
\text { parasitic diseases }\end{array}$ & 4,599 & 1 & $\begin{array}{l}\text { Infectious } \\
\text { diseases and } \\
\text { parasites }\end{array}$ & 7,574 \\
\hline $\begin{array}{l}\text { MDC 17. Neoplastic } \\
\text { disorders } \\
\text { (haematological and } \\
\text { solid neoplasms) }\end{array}$ & 2,950 & 2 & Tumors & 1,669 \\
\hline $\begin{array}{l}\text { MDC 16. Diseases } \\
\text { and disorders of the } \\
\text { blood and blood } \\
\text { forming organs and } \\
\text { immunological } \\
\text { disorders }\end{array}$ & 3,291 & 3 & $\begin{array}{l}\text { Diseases of the } \\
\text { single, } \\
\text { hematopoietic } \\
\text { organs and } \\
\text { some disorders } \\
\text { of the } \\
\text { immunity } \\
\text { mechanism }\end{array}$ & 2,539 \\
\hline $\begin{array}{l}\text { MDC 10. Endocrine, } \\
\text { nutritional and } \\
\text { metabolic diseases } \\
\text { and disorders }\end{array}$ & 8,931 & 4 & $\begin{array}{l}\text { Endocrine } \\
\text { diseases, } \\
\text { nutrition and } \\
\text { metabolism }\end{array}$ & 8,887 \\
\hline $\begin{array}{l}\text { MDC 19. Mental } \\
\text { diseases and } \\
\text { disorders }\end{array}$ & 8,027 & 5 & $\begin{array}{l}\text { Mental and } \\
\text { behavioural } \\
\text { disorders }\end{array}$ & 1,579 \\
\hline $\begin{array}{l}\text { MDC } 20 . \\
\text { Alcohol/drug use and } \\
\text { alcohol/drug induced } \\
\text { organic mental } \\
\text { disorders }\end{array}$ & 1,028 & 5 & $\begin{array}{l}\text { Mental and } \\
\text { behavioural } \\
\text { disorders }\end{array}$ & 1,579 \\
\hline $\begin{array}{l}\text { MDC 01. Diseases } \\
\text { and disorders of the } \\
\text { nervous system }\end{array}$ & 14,799 & 6 & $\begin{array}{l}\text { Diseases of the } \\
\text { nervous } \\
\text { system }\end{array}$ & 5,688 \\
\hline $\begin{array}{l}\text { MDC 02. Diseases } \\
\text { and disorders of the } \\
\text { eye }\end{array}$ & 3,556 & 7 & $\begin{array}{l}\text { Sale of eye } \\
\text { diseases and } \\
\text { attachments }\end{array}$ & 6,965 \\
\hline $\begin{array}{l}\text { MDC 03. Diseases } \\
\text { and disorders of the } \\
\text { ear, nose, mouth and } \\
\text { throat }\end{array}$ & 9,046 & 8 & $\begin{array}{l}\text { Diseases of the } \\
\text { ear and } \\
\text { mastoid } \\
\text { apophysis }\end{array}$ & 6,852 \\
\hline $\begin{array}{l}\text { MDC 05. Diseases } \\
\text { and disorders of the } \\
\text { circulatory system }\end{array}$ & 24,602 & 9 & $\begin{array}{l}\text { Disease } \\
\text { circulator }\end{array}$ & 13,090 \\
\hline $\begin{array}{l}\text { MDC 04. Diseases } \\
\text { and disorders of the } \\
\text { respiratory system }\end{array}$ & 18,802 & 10 & $\begin{array}{l}\text { Respiratory } \\
\text { system } \\
\text { diseases }\end{array}$ & 102,346 \\
\hline $\begin{array}{l}\text { MDC 06. Diseases } \\
\text { and disorders of the } \\
\text { digestive system }\end{array}$ & 20,744 & 11 & $\begin{array}{l}\text { Diseases of the } \\
\text { digestive tract }\end{array}$ & 10,885 \\
\hline $\begin{array}{l}\text { MDC 07. Diseases } \\
\text { and disorders of the } \\
\text { hepatobiliary system } \\
\text { and pancreas }\end{array}$ & 12,766 & 11 & $\begin{array}{l}\text { Diseases of the } \\
\text { digestive tract }\end{array}$ & 10,885 \\
\hline $\begin{array}{l}\text { MDC 09. Diseases } \\
\text { and disorders of the } \\
\text { skin, subcutaneous } \\
\text { tissue and breast }\end{array}$ & 8,586 & 12 & $\begin{array}{l}\text { Diseases of the } \\
\text { skin and } \\
\text { subcutaneous } \\
\text { cellular tissue }\end{array}$ & 12,519 \\
\hline
\end{tabular}




\section{PUBLIC HEALTH AND MANAGEMENT}

\begin{tabular}{|c|c|c|c|c|}
\hline $\begin{array}{l}\text { MDC 08. Diseases } \\
\text { and disorders of the } \\
\text { musculoskeletal } \\
\text { system and } \\
\text { connective tissue }\end{array}$ & 19,006 & 13 & $\begin{array}{l}\text { Diseases of the } \\
\text { osteo-articular } \\
\text { system, } \\
\text { muscles, } \\
\text { connective } \\
\text { tissue } \\
\end{array}$ & 16,829 \\
\hline $\begin{array}{l}\text { MDC 11. Diseases } \\
\text { and disorders of the } \\
\text { kidney and urinary } \\
\text { tract }\end{array}$ & 6,401 & 14 & $\begin{array}{l}\text { Genito-urinary } \\
\text { tract diseases }\end{array}$ & 5,708 \\
\hline $\begin{array}{l}\text { MDC 12. Diseases } \\
\text { and disorders of the } \\
\text { male reproductive } \\
\text { system }\end{array}$ & 2,222 & 14 & $\begin{array}{l}\text { Genito-urinary } \\
\text { tract diseases }\end{array}$ & 5,708 \\
\hline $\begin{array}{l}\text { MDC 13. Diseases } \\
\text { and disorders of the } \\
\text { female reproductive } \\
\text { system }\end{array}$ & 7,979 & 14 & $\begin{array}{l}\text { Genito-urinary } \\
\text { tract diseases }\end{array}$ & 5,708 \\
\hline $\begin{array}{l}\text { MDC 14. Pregnancy, } \\
\text { childbirth and the } \\
\text { puerperium }\end{array}$ & 9,074 & 15 & $\begin{array}{l}\text { Pregnancy, } \\
\text { childbirth and } \\
\text { praise }\end{array}$ & 278 \\
\hline $\begin{array}{l}\text { MDC } 15 . \text { Newborns } \\
\text { and other neonates }\end{array}$ & 7,012 & 16 & $\begin{array}{l}\text { Some diseases } \\
\text { whose origin } \\
\text { lies in the } \\
\text { perinatal } \\
\text { period }\end{array}$ & 74 \\
\hline $\begin{array}{l}\text { MDC 15. Newborns } \\
\text { and other neonates }\end{array}$ & 7,012 & 17 & $\begin{array}{l}\text { Congenital } \\
\text { malformations, } \\
\text { chromosomal } \\
\text { deformations } \\
\text { and } \\
\text { abnormalities }\end{array}$ & 467 \\
\hline $\begin{array}{l}\text { MDC 23. Factors } \\
\text { influencing health } \\
\text { status and other } \\
\text { contacts with health } \\
\text { services }\end{array}$ & 1,014 & 18 & $\begin{array}{l}\text { Symptoms, } \\
\text { signs and } \\
\text { abnormal } \\
\text { results of } \\
\text { clinical and } \\
\text { laboratory } \\
\text { investigators }\end{array}$ & 3,345 \\
\hline $\begin{array}{l}\text { MDC 21. Injuries, } \\
\text { poisoning and toxic } \\
\text { effects of drugs }\end{array}$ & 1,161 & 19 & $\begin{array}{l}\text { Traumatic } \\
\text { injuries, } \\
\text { disorders and } \\
\text { other } \\
\text { consequences } \\
\text { of external } \\
\text { causes }\end{array}$ & 2,210 \\
\hline MDC 22. Burns & 178 & 19 & $\begin{array}{l}\text { Traumatic } \\
\text { injuries, } \\
\text { disorders and } \\
\text { other } \\
\text { consequences } \\
\text { of external } \\
\text { causes }\end{array}$ & 2,210 \\
\hline
\end{tabular}

Since there is no perfect correspondence, where a class of diseases corresponded to several MDCs, the total number of new patients in the respective diagnostic class, registered with family doctors, was evenly divided equally between the relevant CMDs.

For example, patients newly registered having the diagnostic class 11 Diseases of the digestive tract, were equally allocated in MDC 06 Diseases and disorders of the digestive system and MDC 07 Diseases and disorders of the hepatobiliary system.

Analysing the distribution by specialty wards of the inpatient cases, in order to identify a pattern that could be subsequently applied to the new cases registered by the family doctor, we found that some MDCs were hospitalized on 5 or more sections. In this case, the first 2-3 most relevant wards, with the most frequent cases, were selected for each MDC.

Subsequently, the patients from each diagnosis class, reported by the family physicians in the county, were assigned to the specialty wards, based on the mapping with the appropriate MDCs, and to the wards selected as the most relevant. Thus, we calculated the number of patients newly reported by the family doctor who should be hospitalized on each ward, assuming that all new patients would be admitted in the hospital in the studied year. An adjustment was made for the obstetrics and neonatology sections, where most patients do not register with the family doctor, but come directly to the hospital.

In order to link the number of new patients who would theoretically be hospitalized on each type of specialty ward with the number of beds required per type of ward, we studied the hospitalization model of inpatient cases in 2016, in the category I hospitals. The average rate, in all specialties, is $0.020-0.025$ beds per 1 patient, respectively, there are approximately 35 patients per bed. This average of 0.023 coverage rate with beds per county and specialty was applied to newly registered patients by the family doctor, estimated to be hospitalized on each type of section, resulting a specific number of beds on each specialty ward.

Table no 3. The theoretical hospitalization model, applying the rates of the current hospitalization model to the new cases registered with the family doctor

\begin{tabular}{|c|c|c|c|c|}
\hline $\begin{array}{l}\text { Code } \\
\text { of the } \\
\text { dept. }\end{array}$ & & $\begin{array}{l}\text { No. of new } \\
\text { patients } \\
\text { registered } \\
\text { at GP }\end{array}$ & $\begin{array}{l}\text { No. of beds, } \\
\text { as } \\
\text { redistributed } \\
\text { by specialty } \\
\text { departments }\end{array}$ & $\begin{array}{l}\text { No. of } \\
\text { existing } \\
\text { beds per } \\
\text { specialty }\end{array}$ \\
\hline & Total existing & 253273 & 5825 & \\
\hline 1011 & Infectious diseases & 6072 & 140 & 134 \\
\hline 1012 & $\begin{array}{l}\text { Infectious diseases } \\
\text { (pediatrics) }\end{array}$ & 3404 & 78 & 49 \\
\hline 1023 & HIV/AIDS & 3567 & 82 & 22 \\
\hline 1051 & Cardiology & 7772 & 179 & 212 \\
\hline 1071 & Dermatology & 4328 & 100 & 53 \\
\hline 1101 & Endocrinology & 3851 & 89 & 65 \\
\hline 1111 & Gastroenterology & 8776 & 202 & 225 \\
\hline 1131 & Hematology & 3412 & 78 & 56 \\
\hline 1171 & Internal medicine & 8853 & 204 & 449 \\
\hline 1191 & Nephrology & 3919 & 90 & 31 \\
\hline 1202 & $\begin{array}{l}\text { Neonatology } \\
\text { (newborns and } \\
\text { premature) }\end{array}$ & 9698 & 223 & 125 \\
\hline 1231 & Neurology & 4354 & 100 & 164 \\
\hline 1232 & $\begin{array}{l}\text { Neurology } \\
\text { (pediatrics) }\end{array}$ & 3235 & 74 & 35 \\
\hline 1241 & Medical oncology & 4746 & 109 & 144 \\
\hline 1252 & Pediatrics & 38177 & 878 & 367 \\
\hline 1291 & Pulmonology & 23494 & 540 & 204 \\
\hline 1311 & Psychiatry acute & 4480 & 103 & 276 \\
\hline 1312 & $\begin{array}{l}\text { Psychiatry } \\
\text { (pediatrics) }\end{array}$ & 2937 & 68 & 30 \\
\hline 1333.2 & $\begin{array}{l}\text { Psychiatry } \\
\text { (chronic) }\end{array}$ & 3036 & 70 & 201 \\
\hline 1363 & Radiotherapy & 6093 & 140 & 175 \\
\hline 1371 & $\begin{array}{l}\text { Rehabilitation, } \\
\text { physical medicine } \\
\text { and balneology) }\end{array}$ & 7185 & 165 & 150 \\
\hline 1383 & $\begin{array}{l}\text { Cardiovascular } \\
\text { rehabilitation }\end{array}$ & 4439 & 102 & 89 \\
\hline 1393 & $\begin{array}{l}\text { Neurology } \\
\text { rehabilitation }\end{array}$ & 3381 & 78 & 107 \\
\hline 1433 & Rheumatology & 4325 & 99 & 48 \\
\hline 2051 & General surgery & 12577 & 289 & 506 \\
\hline 2083 & Oncology surgery & 7371 & 170 & 180 \\
\hline 2092 & $\begin{array}{l}\text { Surgery and } \\
\text { orthopedics } \\
\text { (pediatrics) }\end{array}$ & 3664 & 84 & 56 \\
\hline 2113 & Plastic surgery & 3271 & 75 & 57 \\
\hline 2173 & Neurosurgery & 3241 & 75 & 58 \\
\hline 2191 & $\begin{array}{l}\text { Obstetrics- } \\
\text { Gynecology }\end{array}$ & 14840 & 341 & 279 \\
\hline 2201 & Ophthalmology & 9093 & 209 & 66 \\
\hline 2211 & $\begin{array}{l}\text { Orthopedics and } \\
\text { traumatology }\end{array}$ & 6203 & 143 & 139 \\
\hline 2221 & ENT & 4199 & 97 & 61 \\
\hline 2293 & Kidney transplant & 4683 & 108 & 0 \\
\hline 2301 & Urology & 6433 & 148 & 108 \\
\hline 6013 & $\begin{array}{l}\text { Maxillofacial } \\
\text { surgery }\end{array}$ & 4321 & 99 & 25 \\
\hline 2123 & Thoracic surgery & & & 30 \\
\hline 2133 & Vascular surgery & & & 25 \\
\hline 2023 & $\mathrm{ICU}$ & & & 278 \\
\hline 1121 & $\begin{array}{l}\text { Geriatrics and } \\
\text { gerontology }\end{array}$ & & & 25 \\
\hline & Total redistributed & 233669 & 5374 & \\
\hline
\end{tabular}

\section{DISCUSSIONS}

Following the analyses, it was found that after adjusting the hospitalization rates according to age groups, the comparison between similar counties (in terms of population 


\section{PUBLIC HEALTH AND MANAGEMENT}

number and the most complex type of hospital) showed great differences in the excess of hospitalization. These could be due to the specific pathology of the population served, the overspecialization of the medical personnel in a specific county, or the size of the county itself.

Adjusting the number of beds by age group and medical migration, showed that in most counties the number of adjusted beds should be higher than the one observed, in accordance with the medical migration.

Elaborating a pattern of hospitalization on specialty wards, based on the history of hospitalizations of various pathologies, allows modelling a theoretical allocation of newly registered patients to the family doctor, on corresponding specialty wards. New patients are a proxy for quantifying the pathology in the population served by the hospital.

The calculation of the number of hospital beds by specialty, according to the allocation of patients registered to the family doctor by the type of the ward, provides the method that was previously missing in the forecast of the number of beds: planning the number of beds according to population and pathology.

Applying this method, a relocation of the hospital beds seems to be necessary. The major discrepancies appear for specialties like internal medicine, general surgery- where the number of necessary beds for the new cases is much lower than the existing number of beds. Controversially, pediatry, pneumology, dermatology, ophthalmology seem to need more beds than the existing ones. But we need to keep in mind that less severe cases (especially for ophthalmology and dermatology) are treated most in ambulatory setting than in hospital.

The current paper did not approach the ambulatory care, since data on ambulatory services are scarce and less routinely collected in Romania.

\section{CONCLUSIONS}

Different methods for the calculation of the number of beds were analysed, as identified in the specialized literature. It turned out that most models use existing demographic information, population trends and/ or current hospital usage indicators in a given geographic area. This information supports the estimation of the total number of beds adequate for the future needs of the population in the studied area. Some models consider the migration of patients from other territories to hospitals in the studied area. None of the studied models, however, considers the morbidity of the patients hospitalized by specialties or the incident pathologies in the population in the respective area.

Consequently, in this paper we developed a model of analysis of the number of beds needed, adjusted with the age structure of the population in the studied county, and with the migration of patients from other counties.

Thus, an overall number of beds needed per county was calculated, adjusted to the needs of the volume and structure of the population served.

In this preliminary stage of the work, the differences and similarities between category I hospitals in six similar counties were studied, and it was found that the activity of the respective hospitals, although they belong to the same category, has different characteristics.

The study made possible to develop a distribution algorithm of the new patients registered by the family doctors, according to pathology. This was based on the allocation by hospital specialty wards of the different pathologies admitted in 2016. Subsequently, we calculated the number of beds estimated to be necessary for the hospitalization of these new patients, by specialty ward, at the county level, assuming that all would be admitted in the hospitals in the studied county in that year.

Because the purpose of the study is to model a structure of a hospital (we choose category I, the most complex) according to the need of the population served, in the next stage of the work the model at the county level will be replicated at the hospital level, using the market share of the hospital.

This paper showed that, after repeated mapping and validation, hospital activity indicators, population data and records from the family doctor could be used successfully in planning the number of beds needed at county level, according to the needs of the population.

\section{REFERENCES}

1. Tate R, MacWilliam L, Finlayson G. A Methodology for Estimating Hospital Bed Need in Manitoba in 2020 Canadian journal on aging - La revue canadienne du vieillissement. 2005;24 Suppl 1:141-51. 10.1353/cja.2005.0056

2. LeTouzé D. Hospital bed planning in Canada: a survey analysis. Int J Health Serv. 1984;14(1):105-126.

3. https://en.wikipedia.org/wiki/Stochastic modelling_insura nce)\#Stochastic modelling. Accessed on. 04.09.2019.

4. http://www.asecib.ase.ro/Dobre/html/capitolul-5-1.html. Accessed on 04.09.2019.

5. Panait CL. Oferta vs cererea de servicii de oferta vs cererea de servicii de oferta vs cererea de servicii de sănătate în contextul demografic tate în contextul demografic tate în contextul demografic actual din România, Management în sănătate. 2011;15(4):13-20.

6. Vajasdi H, Chiriac ND, Minca DG. The assessment of morbidity and the use of hospital services in a county, for better planning hospital infrastructure. Acta Medica Transilvanica. 2019;24(2):1-5.

7. Langley SA, Fuller SP, Messina JP, Shortridge AM, Grady SC. A methodology for projecting hospital bed need: a Michigan case study, Biol Med. 2010 Mar 25;5:4. doi: 10.1186/1751-0473-5-4.

8. Ordinul ministrului sănătăţii nr. $1.408 / 2010$ privind aprobarea criteriilor de clasificare a spitalelor în funcţie de competentă.

9. Chiriac ND, Minca DG, Mușat SN, Ciutan M. Studiul variaţiilor în utilizarea serviciilor spitaliceşti, pe baza datelor de case mix, în anul 2008, România, Management in health. 2010;14(2).

10. Chiriac ND. Aspecte evolutive, variatii ale activitatii spitalicesti si ale practicii chirurgicale -per ansamblu si din perspectiva unor grupuri vulnerabile de pacienti, Management in health. 2010;14(3)

11. Drăgoescu A. Reflectarea în legislaţia românească a continuităţii ca dimensiune a calităţii serviciilor de sănătate, Acta Medica Transilvanica. 2010;2(1):4-6. 